\title{
Clumped or regular? the role of thinning pattern on pine growth and soil water content in dense Aleppo pine post-fire stands
}

\author{
Diana Turrión $^{1}$ (D) Francisco Fornieles ${ }^{1} \cdot$ Susana Bautista $^{1}$
}

Received: 10 April 2021 / Accepted: 6 November 2021 / Published online: 12 November 2021

(C) The Author(s) 2021

\begin{abstract}
The development of silvicultural practices that seek to promote structural heterogeneity is increasingly demanded. This work investigates the effect of thinning spatial pattern on the response to pre-commercial thinning of dense Aleppo pine post-fire stands. On three replicated experimental sites in SE Spain, we applied the following treatments: 600 trees/ha, regular thinning pattern (600R), with residual trees evenly spaced; 600 trees/ha, aggregated thinning pattern (600A), with residual pines arranged in clumps of $\backsim 25$ trees with a local within-clump density of 2500 trees/ha; and control treatment, with no thinning applied (>20,000 trees/ha). We assessed treatment effects on pine growth, size-growth relationships, soil water content, and understory vegetation over the first three years after thinning application. Both regular and aggregated thinning pattern similarly increased pine radial growth. In general, dbh growth rates in response to thinning were faster for smaller trees than for larger trees. The growth rate of pine height was higher for 600R and control than for $600 \mathrm{~A}$, indicating a positive effect on height of both low and very high pine densities. We found a near-term positive effect of aggregated pattern on water availability at the stand level, mostly resulting from enhanced soil water content in the canopy gaps. For both thinning patterns, the recovery of understory vegetation was dominated by resprouter species. This study highlights the potential of aggregated thinning patterns to enhance the complexity and heterogeneity of the pine stands without compromising pine growth, which could be of great use to managing pine forests in Mediterranean areas.
\end{abstract}

Keywords Mediterranean forests · Pinus halepensis - Soil moisture $\cdot$ Spatial pattern Thinning · Understory

Diana Turrión

diana.turrion@ua.es

1 Department of Ecology and IMEM, University of Alicante, Apdo. 99, 03080 Alicante, Spain 


\section{Introduction}

Dense conifer stands and forests are subjected to severe tree competition, which results in stress and reduced growth of individual trees (Cole and Newton 1986; Nambiar and Sands 1993), as well as in high fuel accumulation and fire risk at the landscape scale (Arno and Brown 1991). Thinning is a widespread management practice that aims to redistribute the growth potential of the forest stand, favoring the growth of the remaining trees and benefiting the quality of the residual stand (Daniel et al. 1979; Oliver and Larson 1990). It is often applied as a fuel reduction technique in both natural forests and plantations (Agee and Skinner 2005). Moreover, thinning is expected to contribute to reduce the loss of species and facilitate ecosystem recovery after disturbances (Misson et al. 2003; Hood et al. 2016; Jiménez et al. 2019).

Thinning is commonly applied following regular or dispersed spatial patterns, as evenly spaced neighboring trees are assumed to minimize competition for resources and maximize tree growth (Ferguson et al. 2011). Furthermore, regular tree patterns resulting from self-thinning are often described for mature coniferous forests (Kenkel 1988; Moeur 1997). Accordingly, most previous studies on thinning effects on tree-growth and forest structure have focused on the assessment of different intensities of dispersed-pattern thinning (e.g., Barret, 1982; Mäkinen and Isomäki 2004; Navarro et al. 2010). However, clumped patterns are also common in conifer forests (Lydersen et al. 2013; Youngblood et al. 2004), which can be attributed to a variety of processes that favor tree aggregation and/or increase the spatial heterogeneity and complexity of the forest, including disturbance-based mortality, variation in local site characteristics, microclimate amelioration, aggregated seed deposition, and the interplay between above- and below-ground competition and plant-plant facilitation (Franklin and Van Pelt 2004; Getzin et al. 2006; Martens et al. 2000; North et al. 2004).

The spatial pattern of forest trees may have relevant implications for tree growth, wildlife habitat and the overall ecological functioning of both natural forests and managed forest stands (Boyden et al. 2005; Churchill et al. 2013; Palik et al. 2014). The development of alternative silvicultural practices that seek to promote structural diversity and small-scale variability is gaining momentum in recent years (Puettmann et al. 2015). The importance of tree spatial pattern has been pointed out by several previous studies on retention harvest (Heithecker and Halpern 2007; Urgenson et al. 2013; Venier et al. 2015; de Montigny and Smith 2017). Few additional studies have assessed the role of mechanical brushing and thinning pattern in fuel-reduction (Rambo and North 2009, 2012). However, in general, there is little information on the role of the thinning spatial pattern and the spatial processes involved in shaping thinning effects on trees and stands in dense conifer forests.

In Mediterranean areas, where water scarcity is the major stress factor affecting tree growth (David et al. 2016; Lempereur et al. 2015; Olivar et al. 2014), the effects of thinning on tree performance are expected to be mostly mediated by changes in water availability and water-use efficiency (Bréda et al. 1995; Martín-Benito et al. 2010; Manrique-Alba et al. 2020). It is generally assumed that thinning treatments increase the availability of soil water (Aussenac 2000; Misson et al. 2003; Rodriguez-Calcerrada et al. 2008), at least for certain period after treatment application (Aussenac and Granier 1988), yet woody canopies influence the spatial variation in soil water content in various -and often opposite- ways via interception of precipitation, stemflow, shading, and water consumption (Breshears et al. 1997, 1998; Gómez-Plaza et al. 2001). The spatial pattern of the post-thinning residual trees influences the degree of contrast 
between undercanopy areas and open gaps, and the associated spatial variation of microclimatic conditions and resource availability. This spatial variation in conditions and resources, combined with the variation in the local, short-distance densities of the residual trees, could largely vary the intensity of the local competition and the growth rate of the living trees. There is therefore a need for studies that investigate how the spatial pattern of thinning treatments could modulate the effects of fuel-reduction and/ or restoration thinning on the productivity and health of the target forests.

Aleppo pine (Pinus halepensis Miller) is one of the most abundant tree species in dry and low altitude areas of the Mediterranean Basin (Quezel 2000). Due to the large canopy seed bank of this species, post-fire recruitment in Aleppo pine forests often leads to massive regeneration (Daskalakou and Thanos 2004; Tapias et al. 2001), which causes high intraspecific competition for water, nutrients, and light, and results in reduced tree growth and seed production (De las Heras et al. 2012; Zedler 1995), as well as in fuel accumulation (Trabaud 1976). A density control, pre-commercial thinning is the most common treatment applied to address this problem, which is increasingly widespread due to the increase in the frequency and extent of stand-replacing wildfires in the Mediterranean (Pausas 2004; Pausas and Fernández-Muñoz 2012). Thinning of dense post-fire regenerated Aleppo forests is increasingly conceived as a multi-objective management approach that aims to reduce the fuel load, to increase the resilience of the pine stands, and to improve the conditions of both the pine population and the understory vegetation (Moya et al. 2009). Several previous works have assessed the effect of different intensities of thinning on tree performance for plantations of a variety of pine species, including Aleppo pine plantations (e.g., CrecenteCampo et al. 2009; Lindgren and Sullivan 2013; Martín-Benito et al. 2010; Olivar et al. 2014; Primicia et al. 2013). Fewer works have investigated this issue for postfire Aleppo pine regeneration (e.g., De Las Heras et al. 2004; González-Ochoa et al. 2004). In general, these previous studies showed that thinning increased individual tree growth, ameliorated water stress, and improved water use efficiency of pine trees (Calev et al. 2016; Fernandes et al. 2016), enhanced understory diversity, and accelerated stand maturity (De Las Heras et al. 2004; Moya et al. 2009), yet the importance of these effects depended on other factors such as site quality (González-Ochoa et al. 2004), climatic conditions (Alfaro-Sánchez et al. 2015; Jiménez et al. 2019), initial tree size (Olivar et al. 2014), age of the regeneration at the time of treatment application (Verkaik and Espelta 2006), and time elapsed after thinning (Ruano et al. 2013). To what extent the effects of thinning on Aleppo pine forests could also be sensitive to the spatial pattern of the residual trees is unknown.

In this work, we aimed to investigate the role of the spatial pattern of the residual trees (aggregated versus regular) in shaping the near-term response to thinning of postfire regenerated Aleppo pine forests in dry Mediterranean areas. We specifically investigated the effect of thinning pattern (1) on individual tree growth and size-growth relationships, (2) on the availability and spatial variation of soil water, and (3) on the understory vegetation dynamics over the first three years after thinning application. As baseline null hypothesis, we expected that both aggregated and regular thinning patterns similarly increase pine growth, soil water content and understory cover and diversity as compared with unthinned stands. To take into account the potential variability in treatment effects due to differences in site quality, we replicated this study in three different areas in southeastern Spain, all of which were affected by large standreplacing wildfires in 1994. 


\section{Material and methods}

\section{Study sites}

In the summer of 1994, a series of wildfires burned $\backsim 100,000$ ha of Aleppo pine forests in the Valencia region (East Spain). We conducted this study at three sites that regenerated massively after the 1994 wildfires, producing very dense post-fire stands of Aleppo pine: Mariola, Bocairent, and Albaida (Fig. S1; Supplementary Information). Across sites, pine density ranged between $\backsim 20,000$ and $\backsim 30,000$ pines $\mathrm{ha}^{-1}$, with pine trees ranging between 1.9 and $3.8 \mathrm{~cm}$ in diameter at breast height (dbh), and 2.2 and $3.7 \mathrm{~m}$ in height (Table 1), and exhibiting some degree of self-thinning and self-pruning. The climate in the three sites is dry-subhumid Mediterranean. Local conditions varied among the study sites, reflecting a gradient in elevation, soil organic matter, mean annual precipitation, and mean annual temperature from Mariola, in the hardest extreme of the gradient, to Albaida, which represents the most favorable conditions for pine growth (Table 1). The understory vegetation included the perennial grass Brachypodium retusum (Pers.) P.Beauv., which is the dominant herbaceous species in the study sites, and shrub species such as Quercus coccifera L., Rosmarinus officinalis L., and Ulex palviflorus Pourr.

\section{Experimental design}

For each study site, we selected three 0.5 ha plots within a homogeneous area of dense post-fire Aleppo pine forest. Two of the plots were randomly selected for the application of thinning treatments; the third one was left as unthinned control plot (Control). Two thinning patterns were applied: regular and aggregated, both to a final density of 600 pines per hectare, which falls within the range of high thinning intensity for Aleppo pine forests in drylands (e.g., Manrique-Alba et al. 2020). Regular thinning (600R) left evenly spaced trees throughout the pine stand, while aggregated thinning (600A) left clumps of $\backsim 25$ trees surrounded by clear-cut areas, with within-clump trees thinned to a local density of $\sim 2500$ pines per hectare (Fig. 1). The tree selection for thinning was mechanical (geometrical), and thinning treatments were applied in February 2010, before the growing season. We measured tree growth, understory vegetation, and soil moisture dynamics over a period of 3.5-years.

\section{Data collection}

We assessed tree growth response to treatments by measuring changes in diameter at breast height (dbh), total tree height, and tree crown length from autumn $2011\left(\mathrm{t}_{1}\right)$ to autumn $2013\left(\mathrm{t}_{3}\right)$ on $\backsim 50$ randomly selected pine trees per plot. To avoid any edge affect, trees located at less than $5 \mathrm{~m}$ from the plot borders were excluded from the sampling. In order to check the absence of bias in the selection of the remaining trees as a result of the treatment application, we conducted an initial characterization of tree size by measuring tree height in a subset of 20 sampling trees per plot right after the implementation of the thinning treatments. These initial measurements showed an average height of $3.0 \mathrm{~m}$, with a trend towards higher tree height in $600 \mathrm{~A}$ plots (with an average \pm SE height of $3.4 \pm 0.5 \mathrm{~m}$ ) 


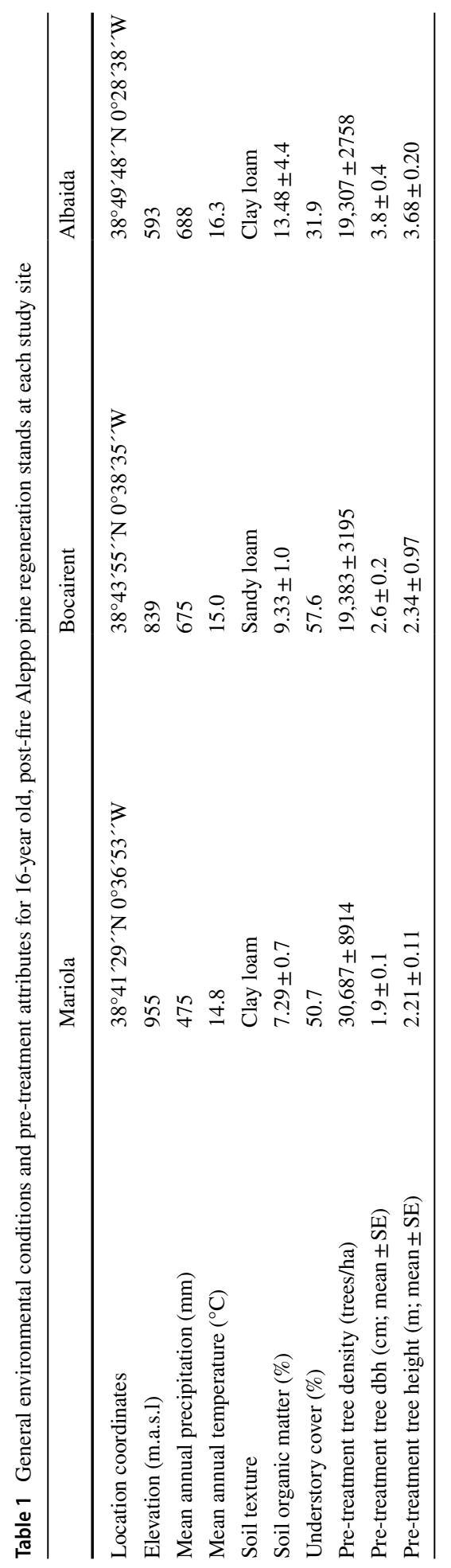




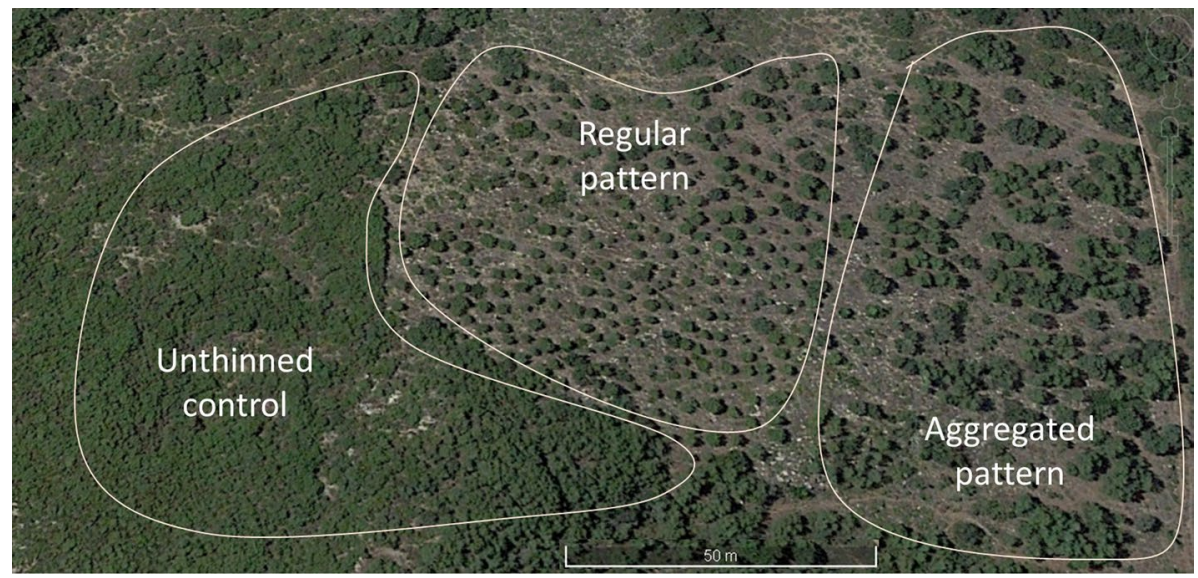

Fig. 1 Aerial image of one of the study site (Bocairent) showing the three types of stand treatments (control, regular, and aggregated pattern) four years after treatment application. Background image from Google Earth Pro (2014)

than in $600 \mathrm{R}(2.8 \pm 0.5 \mathrm{~m})$ and control $(2.7 \pm 0.3 \mathrm{~m})$ plots, yet these differences were not significant.

We measured dbh using an electronic caliper, and measured total tree height with the aid of a telescopic pole. Crown length was calculated as the difference between total height and the height of the crown base (Cruz et al. 2003). To determine the crown base, we considered the lowest insertion point along the tree stem of at least three consecutive living branches (Crecente-Campo et al. 2009). Using a Trephor tool (Rossi et al. 2006), we extracted microcores (15 mm in length and $2 \mathrm{~mm}$ in diameter) at a height of $1.30 \mathrm{~m}$ above ground from 15 pines randomly chosen per plot. The extracted microcores were oven-dried at $60{ }^{\circ} \mathrm{C}$ for $24 \mathrm{~h}$ and polished with sandpaper until the tree rings were clearly visible. The microcores were then photographed using a camera (UEYE UI 1460SECHQ IDS Obersulm, Germany) coupled to a binocular scope device (OPTECH LFZ, Oxford, United Kingdom). Finally, we used the Image J software (Schneider et al. 2012) to analyze the images obtained, measuring tree ring width (TRW) with an accuracy of $0.001 \mathrm{~mm}$. We analyzed TRW back to two years prior the implementation of the thinning treatments, which also contributed to demonstrate no bias in tree selection for thinning.

We monitored soil water content on 30-45 soil moisture probes per plot, by using TDR “Time-Domain Reflectometry" (Topp et al. 1980). The TDR probes (stainlesssteel $12.5 \mathrm{~cm}$ long pins) were vertically installed in the soil and distributed in two sets per plot. One set of 15 probes were regularly distributed along three $30-\mathrm{m}$ transects evenly-spaced within the plot. In order to evenly distribute soil moisture probes under the tree crowns and in the tree gaps, a second set of 30 probes were installed at increasing distances (up to $3 \mathrm{~m}$ ) from the trunk of six randomly selected sampling pine trees. Once installed, we checked the actual canopy cover for each probe and labelled each of them as "undercanopy" or "intercanopy" accordingly. Due to the difficulties to move through the dense mass of pine trees in control areas, the total number of probes installed and monitored in control plots (12 probes along plot transects plus 18 probes at increasing distances from pine trunks) was smaller than in thinned plots. We used a TDR 100 Campbell instrument (Campbell Scientific, Inc. Logan, USA) for 
measurements and the calibration curves of Gray and Spies (1995) with a site-specific calibration factor to calculate the integrated volumetric soil water content at 0 to $12 \mathrm{~cm}$ depth. We took a total of nine measurements throughout study period, with a minimum interval of 1 month between measurements. For each measurement, we estimated the average soil water content per plot and microsite from all the probes installed, using these average values for further analysis.

We monitored understory vegetation dynamics using the point-intercept method (Goodall 1952) on the same three 30-m evenly-spaced transects used for soil moisture monitoring, recording the species intercepted every $20 \mathrm{~cm}$ along the transects. From the vegetation records, we estimated species-specific cover, resprouter and seeder species cover, and total understory cover for each plot. From the species-specific cover values, we estimated the Shannon diversity index (H') for each plot (Shannon and Weaver 1949).

\section{Data analyses}

Relative growth rates $\left(\mathrm{year}^{-1}\right.$ ) for $\mathrm{dbh}$, total height, and crown length were estimated as the difference between the natural logarithm of the respective values for 3-yr $\left(X_{3}\right)$ and 1-yr $\left(X_{1}\right)$ after thinning application relative to the time elapsed between the two measurements: (ln $\left.\mathrm{X}_{3}-\ln \mathrm{X}_{1}\right) /\left(\mathrm{t}_{3}-\mathrm{t}_{1}\right)$ (Evans 1972). To analyze treatment effect on growth rates, we used a randomized block ANOVA, with thinning treatment as fixed factor and site (block) as random factor, on the average values per plot. Treatment effects were judged to be significant at $P \leq 0.05$, and treatment means were compared using Tukey HSD test. To test treatment effects on tree ring width over time, we used Repeated Measures ANOVA, with thinning treatments as between-subject factor. To assess the variation in treatment effect as a function of tree size (at $t_{1}$ ), we used ANCOVA analysis on dbh growth rates, with either dbh or crown length at $t_{1}$ as covariate, and further tested potential differences between pairs of treatments by comparing the slope of the lineal relationships between growth and initial size.

To control for the between-site variation in soil water content due to local differences in the rainfall pattern, we assessed the effects of the thinning pattern (600A vs 600R) and the soil microsite (undercanopy vs intercanopy) on the difference in soil water content between thinned and control plots through time. We used Repeated Measures ANOVA on the average plot-differences between treatments, with thinning pattern, soil microsite, and site as betweensubject factors, and time as within-subject factor. Treatment effects on understory cover and diversity (Shannon index) dynamics were analyzed using Repeated Measures ANOVA on the average values of each variable per plot, with thinning pattern and site as between-subject factors, and time as within-subject factor. Treatment effects on resprouter and seeder species cover was analyzed using two-way ANOVA on the cover values at the end of the study period, with thinning pattern and functional type (resprouter vs seeder) as fixed factors.

Data analyses were performed using R (version 3.2.3; R Development Core Team, 2015) and IBM SPSS $®$ Statistics version 22.0.

\section{Results}

\section{Tree growth response to thinning}

The dbh relative growth rate for the period 2011(t1) — 2013(t3) showed significantly higher values for 600R than for control, with 600A exhibiting intermediate values between $600 \mathrm{R}$ 
Fig. 2 Relative growth rates $\left(\right.$ year $^{-1}$ ) for pine diameter at breast height (dbh), total height and crown length for each thinning treatment for the period between year $3\left(\mathrm{t}_{3}\right)$ and year 1 $\left(\mathrm{t}_{1}\right)$ after treatment application. Values are average values $( \pm 1$ standard error) from the three experimental sites. $\mathrm{F}$ and $p$ values from one-way randomized block ANOVAs are shown.

Treatments with different letters differ statistically $(p \leq 0.05)$ based on Tukey HSD test

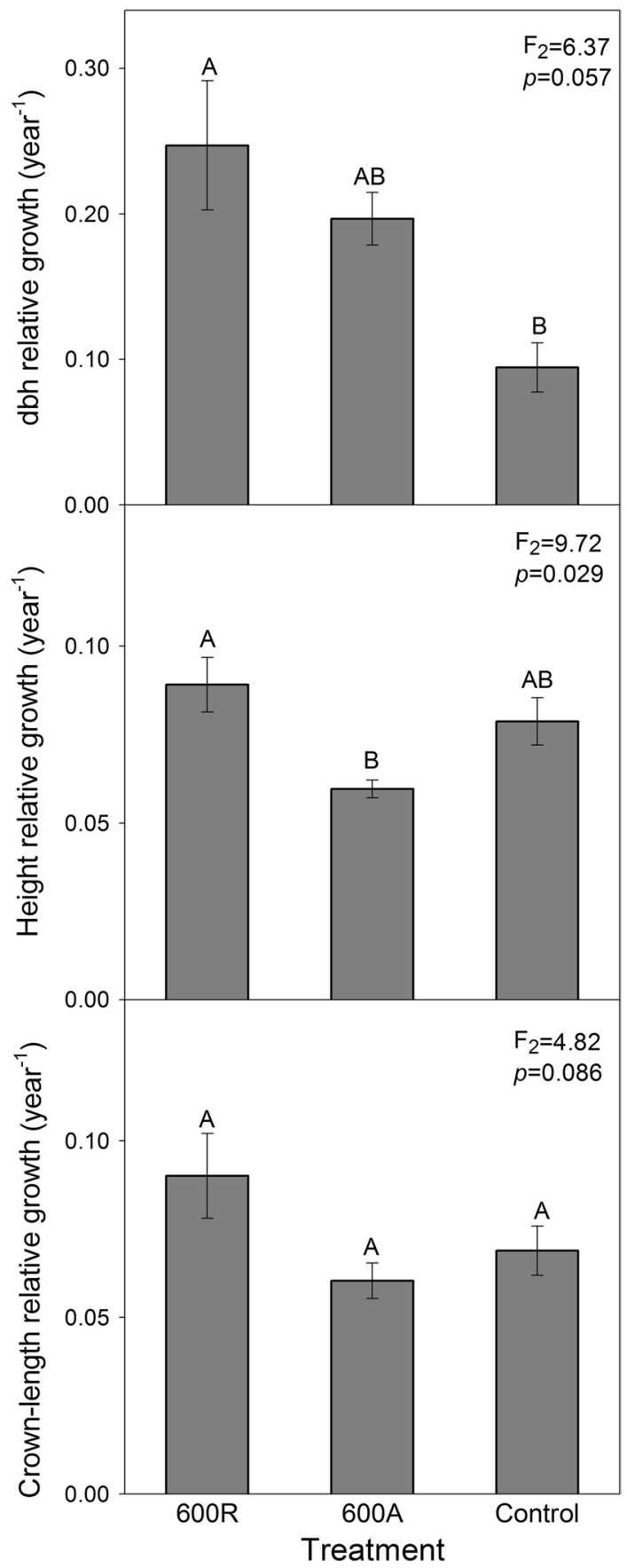

and control (Fig. 2). Height growth rate was higher for 600R than for 600A, yet none of the thinning treatments showed significant differences with the control treatment. The relative growth rate in crown length did not significantly vary among treatments. Despite the large 
variation in average absolute values of dbh, height and crown length among the study sites, the change in the three growth variables considered in response to the thinning pattern was consistent across the sites ("Appendix"), with no significant effect of site factor.

Both time and the interaction between time and treatment showed a significant effect on radial growth as measured by tree-ring width (TRW). While TRW showed no differences among the stands prior to thinning, 600R and 600A showed a clear increase in TRW one year after treatment application and higher values than control over the first three years after thinning that lasted the study period (Fig. 3).

The growth in pine dbh significantly decreased with increasing initial (t1) pine size, either using dbh $(\mathrm{F}=30.67, p<0.001)$ or crown length $(\mathrm{F}=13.40, p<0.001)$ as covariate for pine size, yet this negative relationship was only evident for 600R and 600A treatments (Fig. 4). The slope of the relationship between dbh growth and initial dbh for 600A was higher than for control $(\mathrm{t}=4.48, p<0.001)$ and lower than for $600 \mathrm{R}(\mathrm{t}=-2.51 \mathrm{y} p=0.01)$. The slope for the relationship between dbh growth and initial crown length was higher for both 600R and 600A than for control $(\mathrm{t}=5.72, p<0.001 ; \mathrm{t}=4.88, p<0.001$, respectively), with no differences between the two thinning patterns $(\mathrm{t}=-1.18, p=0.239)$.

\section{Thinning effect on soil water content}

The difference in soil water content between thinned and control areas significantly changed with time $(\mathrm{F}=188.97, p<0.001)$. For all combinations of thinning pattern and position (under and intercanopy) average differences between thinning and control treatments shifted from initial positive values to negative values at the end of the study period, with 600R shifting to negative values earlier than 600A (Fig. 5). The increase in soil water content in the thinned plots as compared with the control plots was significantly higher for $600 \mathrm{~A}$ than for $600 \mathrm{R}(\mathrm{F}=14.15, p=0.007)$, and showed marginally

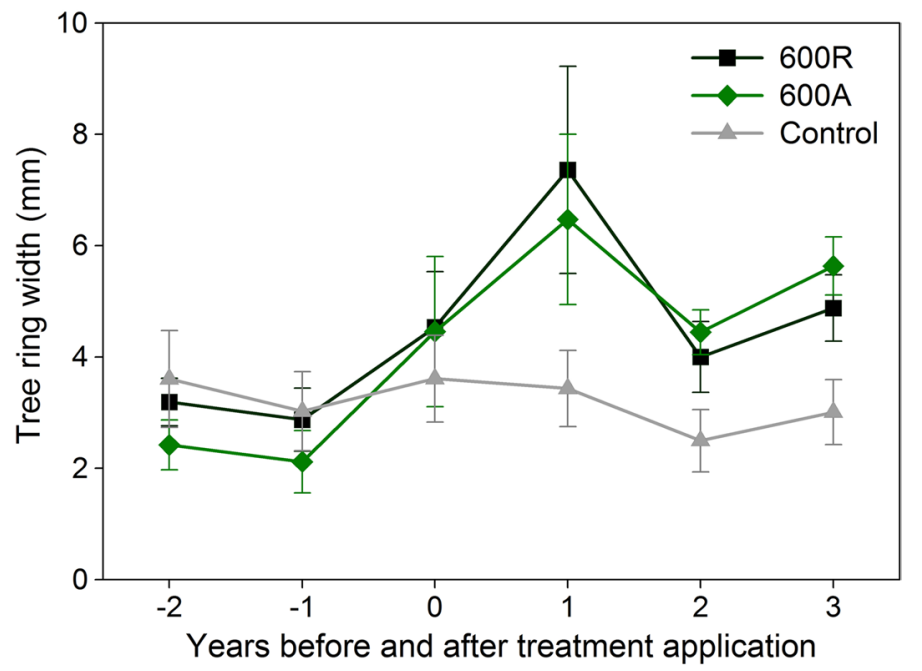

Fig. 3 Variation in tree-ring width as a function of thinning treatment for the period between two years before and three years after treatment application. Values are average values $( \pm 1$ standard error) from the three experimental sites. F and $p$ values from repeated measures ANOVA are shown 

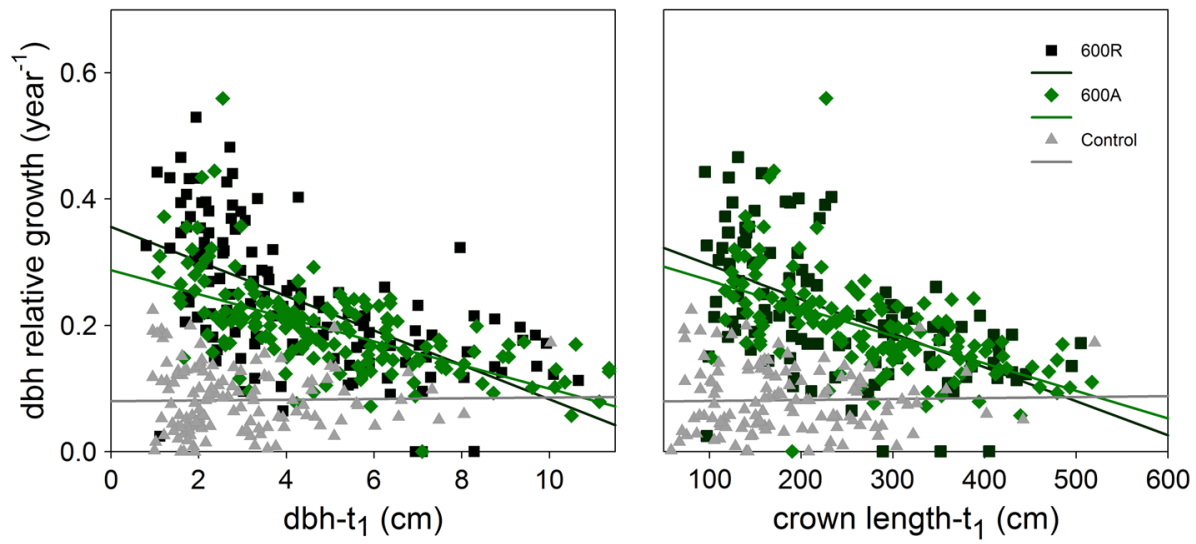

Fig. 4 Size-growth relationships in Aleppo pine as a function of thinning treatment. Relative growth data $\left(\right.$ year $^{-1}$ ) are pine dbh-growth rates between the third $\left(t_{3}\right)$ and the first $\left(t_{1}\right)$ post-thinning year. Initial $\left(t_{1}\right)$ size data are for dbh (left) and crown length (right). Lines represent independent linear regression fit to the data for each thinning treatment

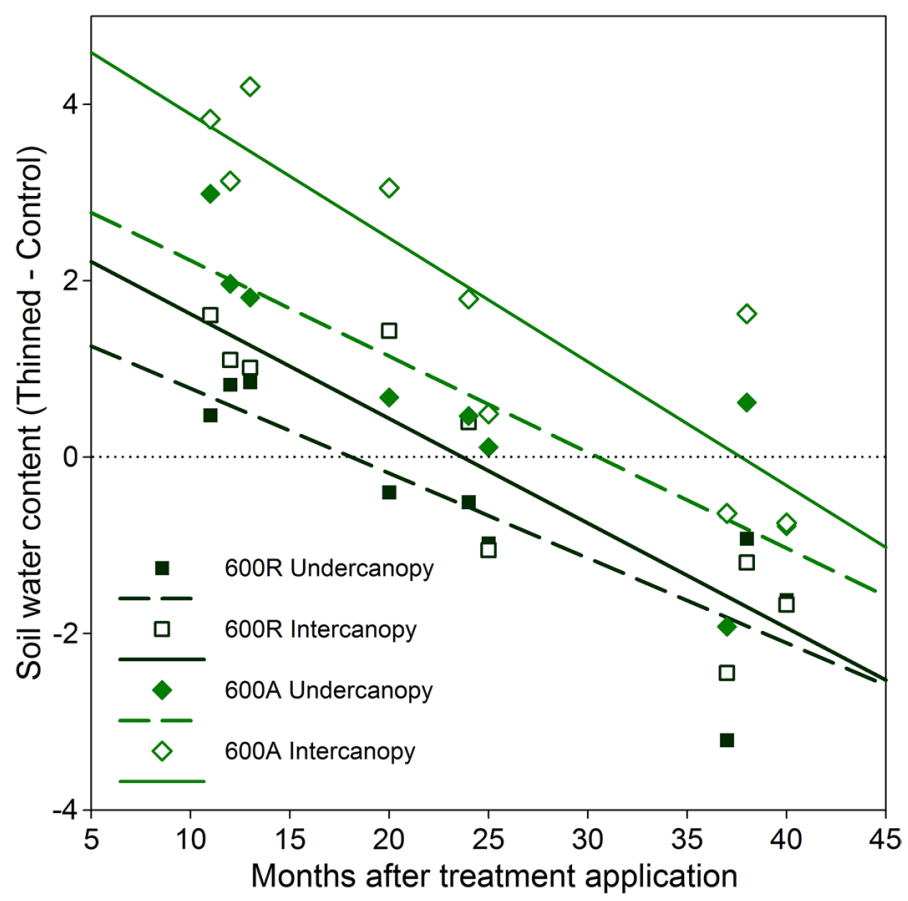

Fig. 5 Variation in the difference in the average soil water content between thinned and control plots $(n=3$ sites) over the study period (3 post-thinning years), as a function of thinning treatment and microsite (undercanopy versus intercanopy) 
significant higher values for intercanopy areas than for undercanopy areas $(F=4.05$, $p=0.084$ ), particularly in the case of aggregate pattern.

Fig. 6 Dynamics of understory cover (top panel) and Shannon diversity index (central panel) over the study period, and total cover of seeder and resprouter species (bottom panel), as a function of thinning treatment. Values are average values $( \pm 1$ standard error) from the three experimental sites $(n=3)$
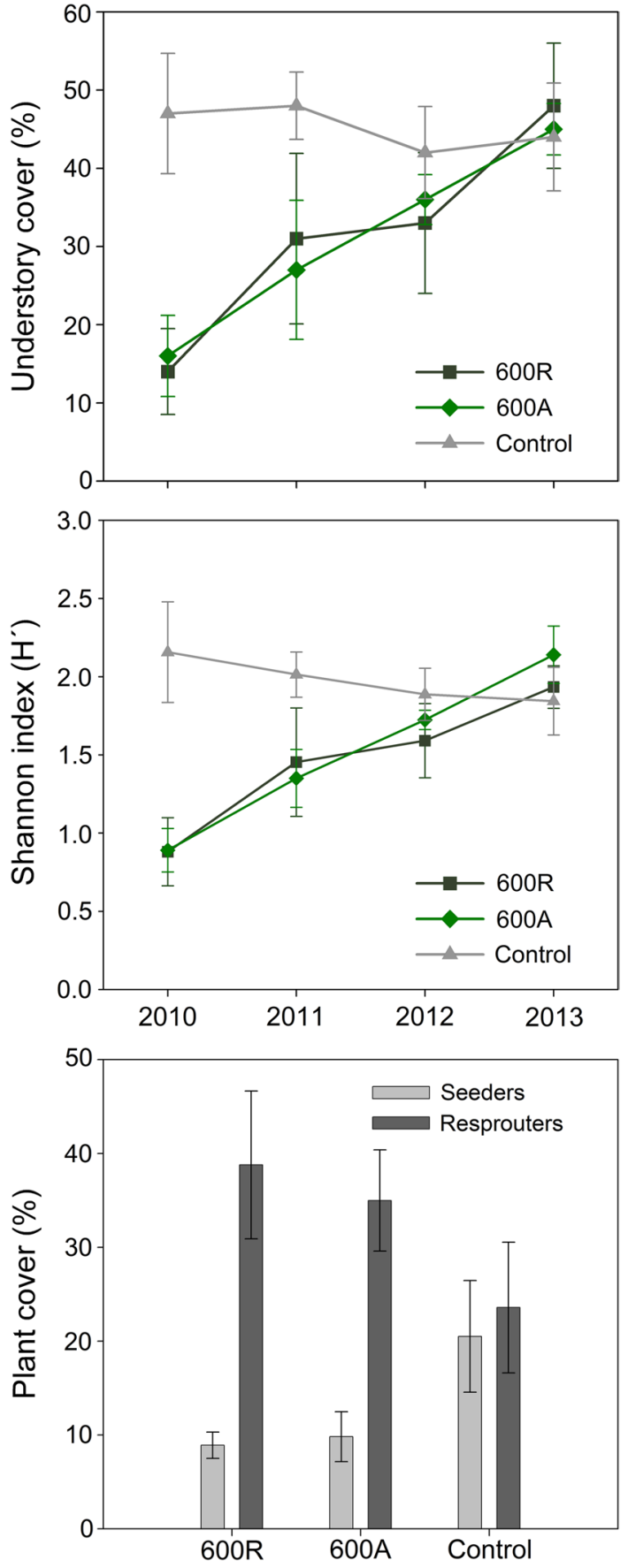


\section{Thinning effect on vegetation understory}

Overall understory vegetation cover and diversity (Fig. 6, top and central panels) did not significantly vary among treatments for the whole study period $(\mathrm{F}=1.58, p<0.282$, and $\mathrm{F}=2.47, p<0.165$, for understory cover and Shannon diversity index, respectively), yet they showed a significant interaction effect between time and treatment $(F=25.07$, $p=0.001$ for understory cover, and $\mathrm{F}=12.66, p=0.007$ for Shannon diversity index), reflecting the contrast between the slightly decreasing trend of understory cover and diversity in the control plots and the strong increasing trend in the thinned plots. Both 600A and 600R thinning patterns exhibited similar understory cover and diversity, which reached the values of the control plots between two and three years after thinning application. Thinning treatment and plant functional type of understory cover showed a marginally significant interaction effect $(\mathrm{F}=3.34, p=0.070)$, reflecting the differences between the control plots, which showed similar percentage of understory resprouter and seeder species, and the thinned plots, with understory vegetation dominated by resprouter species (Fig. 6, bottom panel). The most abundant understory species were the tall shrub Q. coccifera (19\% and $12 \%$ average cover for $600 \mathrm{~A}$ and $600 \mathrm{R}$, respectively) and the perennial grass $\mathrm{B}$. retusum (15\% and $26 \%$ average cover for 600A and 600R, respectively). No recruitment of Aleppo pine was observed.

\section{Discussion}

Our results reveal that the spatial pattern of the post-thinning residual trees slightly modulates thinning effect on pine growth and size-growth relationships. In agreement to our baseline hypothesis, both regular and aggregated pattern similarly increased pine radial growth as compared with the unthinned control stands, yet the magnitude of the effect was slightly higher for the regular pattern, particularly on the smallest trees. The positive effect of thinning on the radial growth of Pinus halepensis is widely known (GonzálezOchoa et al. 2004; Olivar et al. 2014). Tree growth release in thinned stands results from reduced competition and the concomitant increase in water, nutrient, and light availability, with enhanced water availability being the primary driver of increased growth in dry areas (Giuggiola et al. 2016; Manrique-Alba et al. 2020). For any given averaged tree density at the stand level, the short-distance tree density is higher for trees arranged in clumps than for trees arranged in a regular pattern. We could therefore expect lower radial growth of the residual trees in aggregated pattern than in regular pattern due to a relatively higher local competition within the tree clumps. However, due to a greater crown exposure, isolated residual trees may experience higher water stress than trees within denser stands, particularly in drier regions (Bladon et al. 2007), which could lead to lower growth of residual trees in regular than in aggregated thinning pattern. We found only minor differences in the radial growth of Aleppo pines between aggregated and regular thinning pattern, which could indicate that any decrease in water availability due to a higher within-clump tree density was largely offset by a lower evaporative demand within the clumps and/or by the released growth of the tree individuals located along the perimeter of the clumps. The contribution of the clump-edge trees to a positive net outcome for tree growth would depend on the perimeter/area ratio of the clump, with aggregated thinning pattern that leaves relatively small clumps being most effective in promoting overall clump-tree growth. On a 
related forestry practice, several works that assessed the effects of variable retention harvest on the radial growth of the residual conifer trees also found no major differences between dispersed and aggregated retention patterns (Maguire et al. 2006; Palik et al. 2014; Power et al. 2010), which was attributed to the relatively small size of the tree patches left in aggregated retention. The slightly lower pine growth rates found for aggregate pattern as compared with $600 \mathrm{R}$ could also be related to the presence of slightly bigger residual pines in $600 \mathrm{~A}$ than pines in $600 \mathrm{R}$ and control plots at the time of treatment application, probably due to the selection of clumps that included big trees to be left as post-thinning residual clumps. However, the explanatory weight of this incidental factor is minor, if any, as initial size differences between plots were not significant and did not reflect in any variation in the pretreatment tree-ring width.

There is no consensus in the literature about the response to thinning of tree height growth (Zhang et al. 1997). Previous works observed a positive effect of thinning on height growth for Aleppo pine only after five post-treatment years (Ruano et al. 2013), or only for good quality sites (González-Ochoa et al. 2004). In our study, the residual trees with an aggregated distribution showed the lowest height growth rate. This may have resulted from a slightly higher short-distance competition for soil resources in aggregated pines than in regularly-spaced pines combined with an increased growth of the top of the crown in control pines in response to the limited light availability existing in control stands. Also related to differences in light availability, we could expect a higher degree of self-thinning at the base of the tree crown for aggregated and control pines than for regularly-spaced pines, contributing to differences in crown length growth. We found a trend towards lower crown length growth in control and aggregated pines, yet the differences were not significant.

Thinning effects on pine growth are expected to fade over time, as the residual trees increasingly use the higher availability of resources per tree (Aussenac and Granier 1988). For Aleppo pine, Navarro et al. (2010) and Ruano et al. (2013) observed an increase in the radial growth of the residual pines between 1 and 2 years after thinning, and a decline in the increased growth around the 4th-5th year after treatment application. In our study, the tree-ring width (TRW) analysis showed that increased radial growth in response to both aggregated and regular thinning was already noticeable the same year of treatment application, peaking one year after thinning, and slowly declining afterwards. Although thinning effects on pine growth were still important 3 years after treatment application, our results point to a very fast redistribution of stand growth in this species.

An initial rapid tree growth is a key factor determining competitive advantage after disturbances (Oliver and Larson 1990). We found that dbh growth rates in response to thinning were faster for smaller trees than for larger trees, probably reflecting the intrinsic decrease in the relative growth rate of plants with increasing size (Schwinning and Weiner 1998). However, we did not observe any size effect on the growth of control pines, which could be explained by a strong suppression of tree growth in either large or small trees associated to a very intense competition in control stands (Schmitt et al. 1987; Schwinning 1996). Previous works reported non-consistent responses of postthinning growth to tree size, including higher post-thinning growth for smaller trees (Mielikäinen 1978; Moore et al. 1994; Mäkinen and Isomäki 2004), size-independent growth or slightly higher growth for larger trees (Niemistö 1994, Braastad and Tveited 2001), and higher response to thinning for medium-size trees (Pukkala et al. 1998). Higher post-thinning radial growth in larger trees has been associated to a "selection effect" during thinning operations: i.e., the selection of large and vigorous leave trees that already grew faster before thinning (Ferguson et al. 2011). Olivar et al. (2014) observed that the positive effect of soil water content on the radial growth of Aleppo 
pine was significantly higher for dominant trees than for suppressed trees, which was attributed to more developed root systems in larger trees. This variety of responses could be due to differences in stand density, site quality, type of stand (plantation or natural regeneration) and type of thinning. In our study, the negative size-dependence of post-thinning growth resulted in a relative homogenization of pine size few years after thinning, suggesting that it might not be cost-effective to invest in a prior selection of best leave trees for dense stands of Aleppo pine regeneration.

Thinning effects on pine growth can be largely explained by the treatment effects on water availability, probably the main factor controlling radial growth in Aleppo pine (Olivar et al. 2014). Thus, over the first two years after treatment application, water availability increased in thinned plots as compared with controls, particularly for aggregated pattern and intercanopy microsites. These differences disappeared with time and eventually reversed, presumably as result of a higher capacity of the released trees for water use as compared with control pines (del Campo et al. 2014; Jiménez et al. 2019). In contrast to our baseline hypothesis, soil water content was higher for the aggregated pattern, particularly in the intercanopy areas, which contributed to increase overall heterogeneity of $600 \mathrm{~A}$ stands. The higher increase in intercanopy soil water content found for 600A than for 600R suggests a positive effect of increased net precipitation in between-clump gaps due to reduced interception, most notably during the first months after treatment application, before any substantial growth of understory vegetation in the gaps. However, higher water availability in the aggregate-pattern gaps probably benefited only the pines located in the perimeter of the tree clumps, as it did not translate into a general higher pine growth for 600A than for 600R. We found lower soil water content under the pine canopies than between the canopies, which could be due to both rainfall interception by the pine crown and increased water uptake under the tree crowns. However, the fact that between-treatment differences were smaller under the canopies than between canopies suggests that short-term thinning impacts in rainfall interception were more important to water availability than impacts in pine water use. Such an important role of rainfall interception may result from the dominant rainfall pattern in Mediterranean drylands, with around $90 \%$ of the rainfall events yielding less than $10 \mathrm{~mm}$ of rainfall (Mayor et al. 2011), most of which can be intercepted by the tree crowns and further evaporated (Llorens et al. 1997). Nevertheless, thinning impacts mediated by changes in rainfall partitioning are expected to fade with time, as understory cover and water uptake by trees increase (del Campo et al. 2018).

The recovery of the understory vegetation was similar for aggregated and regular thinning patterns, and it was dominated by resprouter species. Since both seeder and resprouter species were present in a similar amount in the dense post-fire pine stands, the dominance of resprouter species in the thinned stands could be attributed on the one hand to the ability of resprouter species to quickly recover above-ground biomass after major disturbances from their belowground resources (Pausas and Vallejo 1999) and, on the other hand, to the inhibitory effect on seed germination of the layer of thinning debris left on the ground after treatment application (Baeza and Vallejo 2008). Although the duration of our study does not allow to conclude about the long-term dynamics of the thinned stands, our findings suggest that the stands that underwent aggregate thinning may develop into a mosaic of small pine patches and maquia, and the regular-thinning stands into a low-density pine forest with a mixed herbaceous-woody understory. However, for dense Aleppo pine stands lacking a significant amount of resprouter species, the long-term impact of thinning on the biotic and spatial structure of the stand could be different, with pioneer seeder species largely colonizing the intercanopy areas until the canopy of the pine forest closed. 


\section{Conclusions and management implications}

Our study illustrates that thinning of dense post-fire Aleppo pine regeneration can largely improve the performance of individual pine trees doubling pine radial growth over the first three years after treatment application, without major differences between aggregated and regular thinning pattern. Despite the higher local density of the within-clump pines in aggregated-pattern stands, the average radial growth of clump trees is not significantly reduced as compared with the average growth of evenly spaced pines, probably due to a higher availability of resources, and associated enhanced growth, for the peripheral trees in the clumps. Our findings also demonstrate a positive near-term effect of the aggregate thinning pattern on water availability at the stand level, mostly resulting from enhanced soil water content in the canopy gaps. The modification of rainfall partitioning seems to be the main mechanisms leading to increased soil water availability and heterogeneity in the aggregated than in the regular thinning pattern.

The spatial pattern of thinning (e.g., regular versus aggregated) could help to achieve different management and restoration goals (Jacobs et al. 2015). When the main objective of the thinning treatment is to enhance pine growth and health, our findings suggest that both regular and aggregated thinning patterns would similarly fulfill that goal. However, restoring Aleppo pine forest resilience and overall functioning could be better achieved by treatments that seek to promote structural and functional complexity within the stands, mimicking natural and healthy forests (Boyden et al. 2005; Churchill et al. 2013), while maintaining similar levels of residual tree growth and productivity. Similarly, it has been suggested that near-natural arrangements of planted trees could increase the resilience of forest stands as compared with regularly spaced stands (Zhang et al. 2019). Furthermore, an aggregated pattern of pine thinning creates a mosaic of tree patches and gaps where understory vegetation can thrive, particularly if resprouter species are present in the area, contributing to increase the structural complexity and heterogeneity of the ecosystem, thus providing niches for biodiversity and promoting higher functional diversity of plants. The contrasting spatial structure created by each thinning pattern may also lead to important differences regarding thinning effects on fire risk. Taking into account that pine density and radial growth were not different between regular and aggregated thinning patterns, both patterns are expected to similarly contribute to reduce fire risk through a decrease in the stand basal area as compared with unthinned stands (Mitsopoulos and Dimitrakopoulos 2014). However, the treeless gaps created by the aggregated pattern contribute to increase the horizontal discontinuity in canopy fuels, which may further reduce the risk of a crown fire in the area (Ruiz-Mirazo and González-Rebollar 2013). Depending on the dominant understory species, these gaps may be mostly covered by resprouter species, which positively contributes to the overall resilience of the stand against fire, or mostly colonized by fire-prone, fast-growing seeder species, which may increase the flammability and combustibility of the plant community (Saura-Mas et al. 2010) and counterbalance the reduction in fire risk promoted by the tree-canopy gaps. In the latter case, mulching with fine-wood thinned debris on the treeless gaps could largely reduce the establishment of fire-prone seeder species (Baeza and Vallejo 2008).

The final density and spatial pattern of the residual trees must be adjusted to the site and stand conditions. Based on our results, for dense, young post-fire regeneration of Aleppo pine in Mediterranean drylands, we recommend aggregated pattern that leaves relative small round tree clumps of residual trees. Clump size and internal pine density should be adjusted so the number of trees located in the perimeter of the clump is of similar order 
than the number of clump-interior trees. For example, tree-clumps of $0.010-0.015$ ha, each of them including 30-50 trees separated by $\backsim 2 \mathrm{~m}$ from each other, could well counterbalance the performance of peripheral and interior trees in the clumps. For sites or areas within the stand with a high likelihood of wind damage, the size of the clumps could be larger. Commonly, selection thinning of Aleppo pine stands targets the smallest trees, aiming to retain large and healthy individuals on the site. However, because of the decreasing growth rates with increasing initial tree size found in our study, the operational selection of the biggest, most vigorous trees may not be cost-effective. This study provides the first assessment of the role played by the spatial pattern of pre-commercial thinning in shaping pine tree growth and soil water availability in post-fire regeneration stands of pine species, and highlights the potential of aggregated thinning pattern to meet the multifaceted goals of current management and restoration approaches through the enhancement of the structural complexity of the forest and the heterogeneity of resource availability.

\section{Appendix}

See Table 2.

Table 2 Tree dbh, total height and crown length for each study site and thinning treatment, 1 year $\left(\mathrm{t}_{1}\right)$ and 3 years $\left(\mathrm{t}_{3}\right)$ after treatment application

\begin{tabular}{|c|c|c|c|c|c|c|c|c|}
\hline \multirow[t]{2}{*}{ Site } & \multirow[t]{2}{*}{ Treatment } & \multirow[t]{2}{*}{$\mathrm{N}$} & \multicolumn{2}{|l|}{ Dbh $(\mathrm{cm})$} & \multicolumn{2}{|c|}{ Total height $(\mathrm{cm})$} & \multicolumn{2}{|c|}{ Crown length $(\mathrm{cm})$} \\
\hline & & & $t_{1}$ & $t_{3}$ & $t_{1}$ & $t_{3}$ & $\mathrm{t}_{1}$ & $t_{3}$ \\
\hline \multirow[t]{3}{*}{ Mariola } & $600 \mathrm{~A}$ & 50 & $2.8 \pm 0.2$ & $4.4 \pm 0.2$ & $258 \pm 9$ & $288 \pm 9$ & $73 \pm 3$ & $86 \pm 22$ \\
\hline & $600 R$ & 42 & $2.6 \pm 0.2$ & $4.4 \pm 0.3$ & $221 \pm 11$ & $263 \pm 13$ & $65 \pm 3$ & $78 \pm 17$ \\
\hline & Control & 40 & $1.9 \pm 0.1$ & $2.3 \pm 0.1$ & $245 \pm 10$ & $277 \pm 10$ & $103 \pm 5$ & $127 \pm 31$ \\
\hline \multirow[t]{3}{*}{ Bocairent } & $600 \mathrm{~A}$ & 54 & $5.4 \pm 0.3$ & $7.7 \pm 0.3$ & $391 \pm 15$ & $442 \pm 15$ & $97 \pm 5$ & $116 \pm 5$ \\
\hline & $600 \mathrm{R}$ & 41 & $3.7 \pm 0.3$ & $6.6 \pm 0.4$ & $258 \pm 21$ & $310 \pm 23$ & $73 \pm 3$ & $85 \pm 4$ \\
\hline & Control & 50 & $2.7 \pm 0.2$ & $3.3 \pm 0.2$ & $270 \pm 10$ & $321 \pm 11$ & $103 \pm 4$ & $131 \pm 6$ \\
\hline \multirow[t]{3}{*}{ Albaida } & $600 \mathrm{~A}$ & 47 & $6.2 \pm 0.3$ & $8.6 \pm 0.2$ & $470 \pm 13$ & $526 \pm 14$ & $144 \pm 5$ & $160 \pm 5$ \\
\hline & $600 \mathrm{R}$ & 59 & $6.3 \pm 0.3$ & $8.6 \pm 0.3$ & $424 \pm 18$ & $491 \pm 20$ & $105 \pm 8$ & $132 \pm 9$ \\
\hline & Control & 45 & $3.7 \pm 0.3$ & $4.5 \pm 0.1$ & $415 \pm 19$ & $488 \pm 23$ & $171 \pm 11$ & $223 \pm 14$ \\
\hline
\end{tabular}

Values are plot averages $( \pm S E)$ of individual pine tree measurements. $N=$ number of pine trees per plot

Supplementary Information The online version contains supplementary material available at https://doi. org/10.1007/s11056-021-09892-9.

Acknowledgements We thank Manuel Ruiz for his invaluable help in the field, Paco Rodríguez for statistical advice, and Jaime Baeza for the provision of experimental areas and his help with the setting up of the experiment. This study was supported by the Spanish Ministry of Science and Innovation through the projects FEEDBACK (CGL2011-30515-C02-01) and DRYEX2 (CGL2017-89804-R).

Authors' contributions SB and DT conceived and designed the work, DT and FF conducted the field experiment and collected the data, DT and SB analyzed and interpreted data, DT drafted the manuscript, SB revised the manuscript. All authors read and approved the final manuscript. 
Funding Open Access funding provided thanks to the CRUE-CSIC agreement with Springer Nature. This study was supported by the Spanish Ministry of Science and Innovation (http://www.ciencia.gob.es/) through the projects FEEDBACK (CGL2011-30515-C02-01) and DRYEX2 (CGL2017-89804-R).

Data availability The datasets used and/or analyzed during the current study are available from the corresponding author upon reasonable request.

\section{Declarations}

Conflict of interest The authors declare that they have no competing interests.

Open Access This article is licensed under a Creative Commons Attribution 4.0 International License, which permits use, sharing, adaptation, distribution and reproduction in any medium or format, as long as you give appropriate credit to the original author(s) and the source, provide a link to the Creative Commons licence, and indicate if changes were made. The images or other third party material in this article are included in the article's Creative Commons licence, unless indicated otherwise in a credit line to the material. If material is not included in the article's Creative Commons licence and your intended use is not permitted by statutory regulation or exceeds the permitted use, you will need to obtain permission directly from the copyright holder. To view a copy of this licence, visit http://creativecommons.org/licenses/by/4.0/.

\section{References}

Agee JK, Skinner C (2005) Basic principles of forest reduction treatments. For Ecol Manage 211:83-96. https://doi.org/10.1016/j.foreco.2005.01.034

Alfaro-Sánchez R, Lopez-Serrano FR, Rubio E, Sanchez-Salguero R, Moya D, Hernandez-Tecles E, De Las HJ (2015) Response of biomass allocation patterns to thinning in Pinus halepensis differs under dry and semiarid Mediterranean climates. Ann for Sci 72:595-607. https://doi.org/10.1007/ s13595-015-0480-y

Arno SF, Brown KJ (1991) Overcoming the paradox in managing wildland fire. West Wildl 17:40-46

Aussenac G (2000) Interactions between forest stands and microclimate: ecophysiological aspects and consequences for silviculture. Ann for Sci 57:287-301. https://doi.org/10.1051/forest:2000119

Aussenac G, Granier A (1988) Effects of thinning on water stress and growth in Douglas-fir. Can J for Res 18(1):100-105. https://doi.org/10.1139/x88-015

Baeza M, Vallejo VR (2008) Vegetation recovery after fuel management in Mediterranean shrublands. Appl Veg Sci 11:151-158. https://doi.org/10.1111/j.1654-109X.2008.tb00213.x

Bladon KD, Silins U, Landhäusser SM, Messier C, Lieffers VJ (2007) Carbon isotope discrimination and water stress in trembling aspen following variable retention harvesting. Tree Physiol 27(7):1065-1071. https://doi.org/10.1093/treephys/27.7.1065

Boyden S, Binkley D, Shepperd W (2005) Spatial and temporal patterns in structure, regeneration, and mortality of an old-growth ponderosa pine forest in the Colorado Front Range. For Ecol Manage 219:4355. https://doi.org/10.1016/j.foreco.2005.08.041

Braastad H, Tveite B (2001) Thinning in spruce and pine stands. Effect of thinning on volume production, mean diameter and diameter of the 800 largest trees per ha. Research Paper No. 10/01. Norwegian Forest Research Institute 28 pp ISSN 0803-2858

Bréda N, Granier A, Aussenac G (1995) Effects of thinning on soil and tree water relations, transpiration and growth in an oak forest (Quercus petraea (Matt.) Liebl.). Tree Physiol 15:295-306. https://doi.org/ 10.1093/treephys/15.5.295

Breshears DD, Rich PM, Barnes FJ, Campbell K (1997) Overstory-imposed heterogeneity in solar radiation and soil moisture in a semiarid woodland. Ecol Appl 7:1201-1215. https://doi.org/10.1890/10510761(1997)007[1201:OIHISR]2.0.CO;2

Breshears DD, Nyhan JW, Heil CE, Wilcox BP (1998) Effects of woody plants on microclimate in a semiarid woodland: soil moisture and evaporation in canopy and intercanopy patches. Int J Plant Sci 159:1010-1017. https://doi.org/10.1086/314083

Calev A, Zoref C, Tzukerman M, Moshe Y (2016) High-intensity thinning treatments in mature Pinus halepensis plantations experiencing prolonged drought. Eur J for Res 1335:551-563. https://doi.org/ $10.1007 / \mathrm{s} 10342-016-0954-\mathrm{y}$ 
Churchill DJ, LarsoAJ DMC, Franklin JF, Hessburg PF, Lutz JA (2013) Restoring forest resilience: From reference spatial patterns to silvicultural prescriptions and monitoring. For Ecol Manage 291:442-457. https://doi.org/10.1016/j.foreco.2012.11.007

Cole EC, Newton M (1986) Nutrient, moisture, and light relations in 5-year-old Douglas-fir plantations under variable competition. Can J for Res 16:727-732. https://doi.org/10.1139/x86-130

Crecente-Campo F, Pommerening A, Rodríguez-Soalleiro R (2009) Impacts of thinning on structure, growth and risk of crown fire in a Pinus sylvestris L. plantation in northern Spain. For Ecol Manage 257:1945-1954. https://doi.org/10.1016/j.foreco.2009.02.009

Cruz M, Alexander M, Wakimoto R (2003) Assessing canopy fuel stratum characteristics in crown fire prone fuel types of western North America. Int J Wildl Fire 12:39-50. https://doi.org/10.1071/WF020 24

Daniel PW, Helms UE, Baker FS (1979) Principles of Silviculture. McGraw-Hill, New York

Daskalakou EN, Thanos CA (2004) Postfire regeneration of Aleppo pine - the temporal pattern of seedling recruitment. Plant Ecol 171:81-89. https://doi.org/10.1023/B:VEGE.0000029375.93419.f9

David TS, Pinto CA, Nadezhdina N, David JS (2016) Water and forests in the Mediterranean hot climate zone: a review based on a hydraulic interpretation of tree functioning. For Syst 25(2):14

De las Heras J, MoyaD, Vega J A, Daskalakou E, Vallejo R, Grigoriadis N, Tsitsoni T, Baeza J, Valdecantos A, Fernandez C, Espelta J, Fernandes P (2012) Post-Fire management of serotinous pine forests. In: Moreira F, Arianotsou M, Corona P De las Heras J(eds) Post-fire management and restoration of southern European forests, managing forest ecosystems, Springer, 151-170. https://doi.org/10.1007/ 978-94-007-2208-8_6

De Las Heras J, González-Uchoa A, López-Serrano F, Simarro ME (2004) Effects of silviculture treatments on vegetation after fire in Pinus halepensis Mill. woodlands (SE Spain) Ann For Sci doi: https://doi. org/10.1051/forest:2004068

de Montigny LE, Smith NJ (2017) The effects of gap size in a group selection silvicultural system on the growth response of young, planted Douglas-fir: a sector plot analysis. Forestry 34:630-641. https://doi. org/10.1093/forestry/cpw068

del Campo AD, Fernandes TJG, Molina AJ (2014) Hydrology-oriented (adaptive) silviculture in a semiarid pine plantation: How much can be modified the water cycle through forest management? Eur $\mathrm{J}$ for Res 133:879-894. https://doi.org/10.1007/s10342-014-0805-7

del Campo AD, González-Sanchis M, Ceacero LA, CJ, García-Prats A, (2018) Rainfall partitioning after thinning in two low-biomass semiarid forests: impact of meteorological variables and forest structure on the effectiveness of water-oriented treatments. J Hydrol 565:74-86. https://doi.org/10.1016/j.jhydr ol.2018.08.013

Evans GC (1972) The quantitative analysis of plant growth. University of California Press, Berkeley and Los Angeles, California

Ferguson DE, Byrne JC, Wykoff WR, Kummet B, Hensold T (2011) Response of ponderosa pine stands to pre-commercial thinning on Nez Perce and Spokane Tribal forests in the Inland Northwest, USA. Res. Pap. RMRS-RP-88. Fort Collins, CO: U.S. Department of agriculture, forest service, rocky mountain research station. 33 p. https://doi.org/10.2737/RMRS-RP-88

Fernandes T, del Campo A, Herrera R (2016) Simultaneous assessment, through sap flow and stable isotopes, of water use efficiency (WUE) in thinned pines shows improvement in growth, tree-climate sensitivity. For Ecol Manag 361:298-308. https://doi.org/10.1016/j.foreco.2015.11.029

Franklin J, Van PR (2004) Spatial aspects of structural complexity in old-growth forests. J for 102:22-29. https://doi.org/10.1093/jof/102.3.22

Getzin S, Dean C, He F, Trofymow J, Wiegand K (2006) Spatial patterns and competition of tree species in a Douglas-fir chronosequence on Vancouver Island. Ecography (cop) 29(5):671-682. https://doi.org/ 10.1111/j.2006.0906-7590.04675.x

Giuggiola A, Ogée J, Rigling A, Gessler A, Bugmann H, Treydte K (2016) Improvement of water and light availability after thinning at a xeric site: which matters more? a dual isotope approach. New Phytol 210:108-121. https://doi.org/10.1111/nph.13748

Gómez-Plaza A, Martínez-Mena M, Albaladejo J, Castillo VM (2001) Factors regulating spatial distribution of soil water content in small semiarid catchments. J Hydrol 253:211-226. https://doi.org/10.1016/ S0022-1694(01)00483-8

González-Ochoa AI, López-Serrano FR, De Las HJ (2004) Does post-fire forest management increase tree growth and cone production in Pinus halepensis? For Ecol Manage 188:235-247. https://doi.org/10. 1016/j.foreco.2003.07.015

Goodall DW (1952) Some considerations of the use of point quadrats for the analysis of vegetation. Aust J Sci Res 5:1-41. https://doi.org/10.1071/BI9520001 
Heithecker TD, Halpern CB (2007) Edge-related gradients in microclimate in forest aggregates following structural retention harvests in western Washington. For Ecol Manage 248:163-173. https://doi.org/10. 1016/j.foreco.2007.05.003

Hood SM, Barker S, Sala A (2016) Fortifying the forest: thinning and burning increase resistance to a bark beetle out-break and promote forest resistance. Ecological Appl 26:1984-2000. https://doi.org/10. 1016/j.foreco.2009.11.033

Jacobs DF, Oliet JA, Aronson J, Bolte A, Bullock JM, Donoso PJ, Landhäusser SM, Madsen P, Peng S, ReyBenayas JM, Weber JC (2015) Restoring forests: What constitutes success in the twenty-first century? New Forest 46:601-614. https://doi.org/10.1007/s11056-015-9513-5

Jiménez MN, Navarro FB, Sánchez-Miranda A, Ripoll MA (2019) Using stem diameter variations to detect and quantify growth and relationships with climatic variables on a gradient of thinned Aleppo pines. For Ecol Manage 442:53-62. https://doi.org/10.1016/j.foreco.2019.03.061

Kenkel N (1988) Pattern of self-thinning in jack pine: testing the random mortality hypothesis. Ecology 69:1017-1024. https://doi.org/10.2307/1941257

Lempereur M, Martin-Stpaul NK, Damesin C, Joffre R, Ourcival JM, Rocheteau A, Rambal S (2015) Growth duration is a better predictor of stem increment than carbon supply in a Mediterranean oak forest: Implications for assessing forest productivity under climate change. New Phytol 207:579-590

Lindgren PMF, Sullivan TP (2013) Long-term responses of tree and stand growth of young lodgepole pine to pre-commercial thinning and repeated fertilization. For Ecol Manage 307:155-164. https:// doi.org/10.1016/j.foreco.2013.06.058

Llorens P, Poch R, Latron J, Gallart F (1997) Rainfall interception by a Pinus sylvestris forest patch overgrown in a Mediterranean mountainous abandoned area I. Monitoring design and results down to the event scale. J Hydrol 199:331-345. https://doi.org/10.1016/S0022-1694(96)03334-3

Lydersen J, North M, Knapp E (2013) Quantifying spatial patterns of tree groups and gaps in mixedconifer forests: reference conditions and long-term changes following fire suppression and logging. For Ecol Manage 304:370-382. https://doi.org/10.1016/j.foreco.2013.05.023

Mäkinen H, Isomäki A (2004) Thinning intensity and long-term changes in increment and stem form of Scots pine trees. For Ecol Manage 203:21-34. https://doi.org/10.1016/j.foreco.2004.07.028

Manrique-Alba A, Beguería S, Molina AJ, González-Sanchis M, Tomàs-Burguera M, del Campo AD, Colangelo M, Camarero JJ (2020) Long-term thinning effects on tree growth, drought response and water use efficiency at two Aleppo pine plantations in Spain. Sci Total Environ 728:138536. https:// doi.org/10.1016/j.scitotenv.2020.138536

Martens S, Breshears D, Meyer C (2000) Spatial distributions of understory light along the grassland/ forest continuum: effects of cover, height, and spatial pattern of tree canopies. Ecol Model 126:7993. https://doi.org/10.1016/S0304-3800(99)00188-X

Martín-Benito D, Del Río M, Heinrich I, Helle G, Cañellas I (2010) Response of climate-growth relationships and water use efficiency to thinning in a Pinus nigra afforestation. For Ecol Manage 259:967-975. https://doi.org/10.1016/j.foreco.2009.12.001

Mayor AG, Bautista S, Bellot J (2011) Scale-dependent variation in runoff and sediment yield in a semiarid Mediterranean catchment. J Hydrol 397:128-135. https://doi.org/10.1016/j.jhydrol.2010.11. 039

Mielikäinen K (1978) Predictability of tree growth. Folia for 363:15

Misson L, Nicault A, Guiot J (2003) Effects of different thinning intensities on drought response in Norway spruce (Picea abies (L.) Karst.). For Ecol Manage 183:47-60. https://doi.org/10.1016/S03781127(03)00098-7

Mitsopoulos ID, Dimitrakopoulos AP (2014) Estimation of canopy fuel characteristics of Aleppo pine (Pinus halepensis Mill.) forests in Greece based on common stand parameters. Eur J Forest Res 133:73-79. https://doi.org/10.1007/s10342-013-0740-z

Moeur M (1997) Spatial models of competition and gap dynamics in old-growth Tsuga heterophylla/Thuja plicata forests. For Ecol Manage 94:175-186. https://doi.org/10.1016/S0378-1127(96)03976-X

Moore JA, Zhang L, Newberry JD (1994) Effects of intermediate silvicultural treatments on the distribution of within-stand growth. Can J for Res 24:398-404. https://doi.org/10.1139/x94-053

Moya D, De Las HJ, López-Serrano FR, Condes S, Alberdi I (2009) Structural patterns and biodiversity in burned and managed Aleppo pine stands. Plant Ecol 200:217-228. https://doi.org/10.1007/ s11258-008-9446-6

Nambiar E, Sands R (1993) Competition for water and nutrients in forests. Can J for 23:1955-1968. https://doi.org/10.1139/x93-247 
Navarro FB, Jimenez MN, Cañadas EM, Gallego E, Terrón L, Ripoll MA (2010) Effects of different intensities of overstory thinning on tree growth and understory plant-species productivity in a semi-arid Pinus halepensis Mill. afforestation. For Syst 19:410-417. https://doi.org/10.5424/fs/2010193-8858

Niemistö P (1994) First commercial thinning in a Scots pine standby using thinning from below, from above, or quality thinning. Folia For 19-32

North M, Chen J, Oakley B, Song B, Rudnicki M, Gray A, Innes J (2004) Forest stand structure and pattern of old -growth western Hemlock/Douglas fir and mixed-conifer forests. For Sci 50(3):299311. https://doi.org/10.1093/forestscience/50.3.299

Olivar J, Bogino S, Rathgeber C, Bonnesoeur V, Bravo F (2014) Thinning has a positive effect on growth dynamics and growth-climate relationships in Aleppo pine (Pinus halepensis) trees of different crown classes. Ann for Sci 71:395-404. https://doi.org/10.1007/s13595-013-0348-y

Oliver C, Larson B (1990) Forest stand dynamics. McGraw-Hill Inc, New York

Palik BJ, Montgomery RA, Reich PB, Boyden SB (2014) Biomass growth response to spatial pattern of variable-retention harvesting in a Northern Minnesota pine ecosystem. Ecol Appl 24(8):20782088. https://doi.org/10.1890/13-1173.1

Pausas JG (2004) Changes in fire and climate in the eastern Iberian Peninsula (Mediterranean Basin). Clim Change 63:337-350

Pausas JG, Fernández-Muñoz S (2012) Fire regime changes in the Western Mediterranean Basin: From fuel-limited to drought-driven fire regime. Clim Change 110:215-226. https://doi.org/10.1007/ s10584-011-0060-6

Pausas JG, Vallejo VR (1999) The role of fire in European Mediterranean Ecosystems. In: Chuvieco E (ed) Remote sensing of large wildfires in the European Mediterranean basin. Springer-Verlag, Berlin, pp 3-16

Primicia I, Camarero JJ, Imbert JB, Castillo FJ (2013) Effects of thinning and canopy type on growth dynamics of Pinus sylvestris: Inter-annual variations and intra-annual interactions with microclimate. Eur J for Res 132:121-135. https://doi.org/10.1007/s10342-012-0662-1

Google Earth Pro V 7.3.2.5776., June 30, 2013. Bocairent, Valencia, Spain. 3843'55.07"N 0³8'36.12"W, Eye alt 1002 m. Maxar Technologies 2020. http://www.earth.google.com [viewed April 15, 2020]

Puettmann KJ, Scott MW, Susan CB, Pablo JD, Lars D, Girma A, Brian DH, Thomas K, Lu YC, Susanna N, Francis EP, Toshiya Y, Jürgen B (2015) Silvicultural alternatives to conventional even-aged forest management - what limits global adoption? For Ecosyst 2:8

Pukkala T, Miina J, Kellomäki S (1998) Response to different thinning intensities in young Pinus sylvestris. Scand J for Res 13:141-150. https://doi.org/10.1080/02827589809382970

Quezel P (2000) Taxonomy and biogeography of Mediterranean pines (Pinus halepensis and P. brutia), In: Ne'eman G, TL (Ed.), Ecology, biogeography and management of Pinus halepensis and P. brutia Forest Ecosystems in the Mediterranean Basin. Backhuys Publishers, Leiden, pp. 1-12

Rambo TR, North MP (2009) Canopy microclimate response to pattern and density of thinning in a Sierra Nevada forest. For Ecol Manage 257:435-442. https://doi.org/10.1016/j.foreco.2008.09.029

Rambo TR, North MP (2012) Influence of fuel-reduction forest thinning on growth of an arboreal forage lichen. For Ecol Manage 263:208-215. https://doi.org/10.1016/j.foreco.2011.09.036

Rodriguez-Calcerrada J, Mutke S, Alonso J, Gil L, Pardos JA, Aranda I (2008) Influence of overstory density on understory light, soil moisture, and survival of two underplanted oak species in a Mediterranean montane Scots pine forest. Investig Agrar Sist y Recur For 17:31-38

Rossi S, Anfodillo T, Menardi R (2006) Trephor: a new tool for sampling microcores from tree stems. Iawa J 27:89-97. https://doi.org/10.1163/22941932-90000139

Ruano I, Rodríguez-García E, Bravo F (2013) Effects of pre-commercial thinning on growth and reproduction in post-fire regeneration of Pinus halepensis Mill. Ann for Sci 70:357-366. https://doi.org/ 10.1007/s 13595-013-0271-2

Ruiz-Mirazo J, González-Rebollar JL (2013) Growth and structure of a young Aleppo pine planted forest after thinning for diversification and wildfire prevention. For Syst 22:47-57

Saura-Mas S, Paula S, Pausas JG, Lloret F (2010) Fuel loading and flammability in the Mediterranean Basin woody species with different post-fire regenerative strategies. Int J Wildl Fire 19:783-794. https://doi.org/10.1071/WF09066

Schmitt J, Eccleston J, Ehrhardt DW (1987) Dominance and sup-pression, size-dependent growth and self-thinning in a natural Impatiens capensis population. J Ecol 75:651-665. https://doi.org/10. $2307 / 2260197$

Schneider CA, Rasband WS, Eliceiri KW (2012) NIH image to imageJ: 25 years of image analysis. Nat Methods 9:671-675. https://doi.org/10.1038/nmeth.2089 
Schwinning S (1996) Decomposition analysis of competitive sym-metry and size structure dynamics. Ann Bot 77:47-57. https://doi.org/10.1006/anbo.1996.0006

Schwinning S, Weiner J (1998) Mechanisms determining the degree of size asymmetry in competition among plants. Oecol 113:447-455. https://doi.org/10.1007/s004420050397

Shannon CE, Weaver W (1949) The mathematical theory of communication. University of Illinois Press, Urbana

Tapias R, Gil L, Fuentes-Utrilla P, Pardos JA (2001) Canopy seed banks in Mediterranean pines of south eastern Spain: a comparison between Pinus halepensis Mill., P. pinaster Ait., P. nigra Arn. and $P$. pinea L. J Ecol 89:629-638. https://doi.org/10.1046/j.1365-2745.2001.00575.x

Topp GC, Davis JL, Annan AP (1980) Electromagnetic determination of soil water content: measurements in coaxial transmission lines. Water Resour Res 16:574-582. https://doi.org/10.1029/WR016i003p 00574

Trabaud L (1976) Inflammabilité et combustibilité des principales espèces des garrigues de la région méditerranéenne. Oecol Plantarum 11:117-136

Urgenson LS, Halpern CB, Anderson PD (2013) Level and pattern of overstory retention influence rates and forms of tree mortality in mature, coniferous forests of the Pacific Northwest, USA. For Ecol Manage 308:116-127. https://doi.org/10.1016/j.foreco.2013.07.021

Venier LA, Dalley K, Goulet P, Mills S, Pitt D, Cowcill K (2015) Benefits of aggregate green tree retention to boreal forest birds. For Ecol Manage 343:80-87. https://doi.org/10.1016/j.foreco.2015.01.024

Verkaik I, Espelta JM (2006) Post-fire regeneration thinning, cone production, serotiny and regeneration age in Pinus halepensis. For Ecol Manage 231:155-163. https://doi.org/10.1016/j.foreco.2006.05.041

Youngblood A, Max T, Coe K (2004) Stand structure in eastside old-growth ponderosa pine forests of Oregon and northern California. For Ecol Manage 199:191-217. https://doi.org/10.1016/j.foreco.2004.05. 056

Zedler P (1995) Fire frequency in southern California shrublands: biological effects and management options. In: Keeley JE, Scott T (eds) Brushtires in California wildlands: ecology and resource management. International association of wildland fire, Fairfield WA, pp 101-112

Zhang S, Burkhart HE, Amateis RL (1997) The influence of thinning on tree height and diameter relationships in Loblolly pine plantations South. J Appl for 21:199-205. https://doi.org/10.1093/sjaf/21.4.199

Zhang G, Hui G, Hu Y, Zhao Z, Guan X, von Gadow K, Zhang G (2019) Designing near-natural planting patterns for plantation forests in China. Forest Ecosyst 6:28. https://doi.org/10.1186/ s40663-019-0187-x

Publisher's Note Springer Nature remains neutral with regard to jurisdictional claims in published maps and institutional affiliations. 